Höhere Mathematik für den Praktiker

An Stelle einer fünfte Auflage des "Lehrbuchs der Differential- und Integralrechnung" von $H$. A. Lorentz. Neu bearbeitet von Prof. Dr. G. Joos und Prof. Dr. Th. Kaluza. Pp. xii +364 . (Leipzig : Johann Ambrosius Barth, 1938.) 23 gold marks.

"WTHY do men write big books ?" asked Bernard Shaw. "Because they haven't time to write small ones!" The authors of this small book must have expended a great deal of time and energy in selecting essentials and presenting the mathematical methods and results which are most needed by engineers and physicists. The range covered is amazingly wide.

Starting with permutations, combinations, and the binomial theorem, we go on to probability, determinants, complex numbers, progressions, exponen. tials and logarithms, trigonometry, vectors and analytical geometry of two and three dimensions. These subjects receive only a few pages apiece, but the talent of the authors for compression makes the treatment really valuable. Much more space is given to the differential and integral calculus, which go as far as maxima and minima of functions of several variables and the transformation of double and triple integrals. There is a short section on Fourier's series and integral, including the use of the harmonic analyser. Differential equations are solved numeric. ally and graphically, as well as by the usual elementary methods, and there is a brief account of partial differential equations. This is followed by a section on the calculus of variations. There are seven pages on functions of a complex variable, and in this the authors succeed in giving an intelligible account of conformal representation and Cauchy's theorem, with an application to the evaluation of a definite integral by means of contour integration. The book concludes with answers to examples and an index.

Naturally there are many portions of this book which the specialist will condemn as inadequate, but the object of the authors is to give a wide general view, and their work will be welcomed as a gallant counter-attack against the forces of narrow specialization.

H. T. H. Piaggio.

Histoire générale du tissu

Document No. 2: Tissus anciens. Partie 1: Le Kaunakès; étude critique d'après les textes, les monuments, figurés et les survivances supposées du tissu. Par Emile Cherblanc. Pp. 66+16 plates. (Paris : Les Éditions d'Art et d'Histoire, 1937.) 30 francs.

TN this second study in the series dealing with the 1 history of weaving, M. Emile Cherblanc reviews the evidence from all sources, including that now made available by recent archæological discovery in Irak, bearing on the nature of the garment, reputedly of Chaldean origin and known to classical writers, notably Aristophanes, Menander and Pollux, as the kaunakes ( $\varkappa \alpha \cup \vee \alpha ́ x \eta s)$. M. Heuzey in 1886 in a communication to the Académie des Inscriptions et Belles Lettres concluded, on the evidence of two monuments, as well as the literary sources, that the kaunakes was an oblong mantle of wool with a long pile, which was worn draped simply about the body.

In the light of the evidence now brought under review, M. Cherblane concludes that the examples from the monuments upon which M. Heuzey relied represent two distinct classes of material, one a sheepskin of which the fleece was retained, and the second composed of skins joined and sewn together. In the third and second millennium B.c. and the preHellenic period, the term did not refer to a fabric. In the time of Aristophanes it was used of a garment of Persian origin made of a thick and heavy material, in which a large quantity of wool was used. This was worn on the shoulders and probably was semicircular in form like the $x \alpha \pi \alpha \varphi \phi_{0 x \alpha \tau \alpha \zeta}$ of the modern Greek shepherd, and possibly with the same goat-skin texture. The author maintains that the allusions to the kaunakes in all classical authors, with the exception of Martial, can be shown to agree with the meaning of a garment of sheepskin which retains the fleece. An examination of the Coptic 'knot' pile fabric, which through the 'point sarrasinois' had an important influence on the Eastern and European carpet fabrics, shows it to be entirely Egyptian in origin and unrelated to the kaunakes.

M. Cherblanc's ably reasoned study is very fully illustrated by material from the monuments and diagrammatic sketches of the technical points and processes involved in the argument.

\section{Contributions to the Microscopic Anatomy of the} Pancreas

By Paul Langerhans (Berlin, 1869). Reprint of the German original with an English translation and an introductory essay by Dr. H. Morrison. Pp. 39. (Baltimore, Md.: Johns Hopkins Press; London : Oxford University Press, 1937.) 4s. 6d. net.

7 HIS little work, now reprinted from the 1 Bulletin of the Institute of the History of Medicine (March 1937), contains one of the classics of medicine, which was presented by the medical student Paul Langerhans in 1869 at the age of twenty-one years as his inaugural thesis for the degree of doctor of medicine at the Berlin Faculty. The thesis constitutes not only the first detailed account of the microscopical anatomy of the pancreas, a subject which had hitherto been neglected by anatomists and physiologists but also the first description of peculiar groups of cells in this organ, the nature of which Langerhans was unable to explain. In 1893, however, they received the name of "islands of Langerhans" from the French histologist Laguesse, who first suggested that they were the seat of the internal secretion of the pancreas; but it was not until 1921, or more than fifty years after the appearance of Langerhans' thesis, that insulin, the specific cure of diabetes, was isolated from these cells by Banting and Best of Toronto.

In addition to the German original and English translation of the thesis, the work contains a short account of the life and work of Langerhans, who died at Madeira at the early age of forty-one years; there is also a list of his publications and portraits at different ages. 